Article

\title{
Students' Differences, Societal Expectations, and the Discursive Construction of (De)Legitimate Students in Germany
}

\author{
Nadine Bernhard \\ Center for Comparative and International Education, Humboldt Universität zu Berlin, Germany; \\ E-Mail: nadine.bernhard@hu-berlin.de
}

Submitted: 7 May 2021 | Accepted: 9 July 2021 | Published: 16 September 2021

\begin{abstract}
At higher education institutions (HEI), which for centuries served only to educate the elite, the composition of the student body is increasingly changing towards greater social and cultural diversity. Students' differences are also the focus of this article, but not with a specific emphasis on preselected categories. Instead, the article asks how students in teaching in higher education (HE) are represented in the print media and professional discourse in Germany, i.e., which categories of difference are constructed as relevant in HE teaching contexts, which are normalized and (de)legitimized, and what is expected of $\mathrm{HEl}$ concerning these differences. Second, to what extent does this change over time, particularly concerning the new circumstances of Corona-based digital teaching in 2020? The contribution is based on a combination of discourse theory and neo-institutional organizational sociology. Discourses are a place where social expectations towards organizations are negotiated and constructed. Simultaneously, the discourses construct a specific understanding of $\mathrm{HE}$, making visible openings and closures concerning different groups of students. Which students are constructed as legitimate, desirable, at risk of dropping out, or a risk for $\mathrm{HE}$ quality? Based on qualitative content analysis, the article shows that it is less the traditional socio-structural categories such as gender, social or ethnic origin, or impairments, that are discussed to be relevant in $\mathrm{HE}$ teaching contexts. The reproduction of inequality and the associated discrimination is hardly discussed. The focus is instead on the students' differences concerning individualizable characteristics, competencies, or study practices. Even though many of these individualized differences are conveyed via socio-structural categories, this connection is often not considered in the discourses.
\end{abstract}

\section{Keywords}

discourse analysis; diversity; doing difference; higher education; higher education teaching; inclusion; societal expectations; social inequality

\section{Issue}

This article is part of the issue "Education, Politics, Inequalities: Current Dynamics and Perspectives" edited by Kenneth Horvath (University of Lucerne, Switzerland) and Regula Julia Leemann (University of Teacher Education FHNW, Switzerland / University of Basel, Switzerland).

(C) 2021 by the author; licensee Cogitatio (Lisbon, Portugal). This article is licensed under a Creative Commons Attribution 4.0 International License (CC BY).

\section{Introduction}

In recent decades, various developments have led to an increasing diversification of the student body in many countries: The transformation process towards a knowledge society was accompanied by educational expansion and the so-called massification of universities (Altbach et al., 2017). For example, the rate of first-year students of an age cohort in Germany increased from $37 \%$ in
2002 to 56\% in 2019 (Statistisches Bundesamt, 2019). Higher education institutions (HEI) are becoming increasingly important in the context of lifelong learning so that different age cohorts with different educational biographies are seeking access to higher education (HE; see, e.g., Altbach et al., 2017). An increased permeability from vocational to HE reinforces this development (e.g., Bernhard, 2017). At the same time, the student body increasingly internationalizes (e.g., Streitwieser, 2014). 
Finally, the signing of the Convention on the Rights of Persons with Disabilities has rekindled calls for inclusion at universities (e.g., Powell, 2016).

Assumingly, these developments pose new challenges for $\mathrm{HE}$ systems, in particular like the one in Germany. Germany is known for its highly segregated and socially inequitable education system with early selection into an academic or a vocational track within the school system (Powell \& Solga, 2011). As a consequence, Germany traditionally has had a preselected and relatively socially homogeneous student body. The academic upper secondary school track leads to the Abitur, which is the general HE entrance qualification and authorizes students to enter into all types of HEl. This is the traditional and main road to HE in Germany. Other routes are via vocation-oriented schools where students often gain the $\mathrm{HE}$ entrance qualification for universities of applied sciences (Fachhochschulreife). Besides opportunities to reach the Abitur in evening classes or other forms of adult education, recent regulative changes also allow vocationally qualified students to enter HEI (Bernhard, 2017). Due to these developments and those mentioned above (e.g., internationalization), the diversification of the student body can also be witnessed in the German HE system. At the same time, Germany does not have a long tradition of lifelong learning at HEI and started using the HE system for further academic education comparatively late (Schuetze \& Slowey, 2012; Wolter \& Schäfer, 2020). In Germany, HE teaching is traditionally less critical for a career in academia than in other countries, especially those where tuition fees are high and student satisfaction is of great importance. In this respect, further training in HE didactics where teachers could become more sensitive to students' differences is not obligatory in most German HEl, in contrast to other national systems such as in England. Germany thus represents an exciting case where increasing diversification meets a traditionally highly segregated system in which university teaching and its professionalization still play a rather subordinate role.

Against this background, by analyzing print media and the professional discourses, this article looks at how students in HE teaching have been represented in Germany in recent years and what is expected of HEI concerning these differences. However, rather than concentrating only on previously defined and considered as important categories of diversity, I examine which categories of difference are constructed as relevant in $\mathrm{HE}$ teaching contexts in media and professional discourses. I focus on teaching because $\mathrm{HE}$ teaching is the principal place where students and the HEl, represented by its teachers, interact, and it is thus the main place where teachers act as gatekeepers for future life chances.

This article extends existing research on several points: It examines which students' differences have been discursively created and compares the results of a print media and professional discourse of HE teachers between 2010 and 2020 in Germany. Therefore, it can extrapolate which differences are constructed as relevant for HE teaching contexts and give also a first hint of how pandemic-induced online teaching during the Corona crisis in 2020 interrelates with the found structures. Moreover, the societal and professional expectations towards HE organizations and teachers are analyzed and compared in the discourses.

In public and professional discourses, societal and professional expectations towards organizations like universities are negotiated and constructed. According to organizational sociological assumptions (Hasse \& Krücken, 2005), these expectations are a point of orientation for the actions of organizations like universities and their teachers to remain legitimate. At the same time, discourses not only represent expectations but also construct a social reality (Keller, 2006, 2011). The construction of students' differences and their evaluation in the context of HE teaching in discourse are then closely linked to questions of social recognition: Which students are constructed as (de)legitimate, desirable, at risk of dropping out, or even a risk for HE quality? In this way, examining the construction of difference and the reported practices of teachers in the discourses enables an analysis of (discursive) social opening and closing processes in the HE system.

To answer these research questions, I first discuss the state of research and the theoretical concepts. Then, the research design is explained. In the results, I compare the constructed differences of students, their intersections, their evaluation, and the accompanying (de)legitimation and normalization of students in the media and professional discourse. Finally, the reported and required practices in dealing with students and thus the environmental expectations at universities are also presented.

\section{State of Research and Theoretical Conceptualization}

In this section, I will provide an initial overview of the state of research. Research on student differences is extremely diverse and, therefore, the overview here can only be cursory. Following the state of research, the theoretical concepts that underlie this work will be presented.

\subsection{State of Research}

When looking at differences of students, research often focuses on aspects like selectivity of access to HE (e.g., Duru-Bellat et al., 2008; Goastellec \& Välimaa, 2019). Other research addresses issues of student diversity during their studies. Areas being investigated include the role of support structures for students (e.g., Smith, 2007; Unangst \& Streitwieser, 2018), the governance of diversity at universities (e.g., Linde \& AuferkorteMichaelis, 2018), students' experiences of discrimination (e.g., Hopkins, 2011; Lee \& Rice, 2007; Stern et al., 2018), and students' success, progression, and practices. (e.g., Lange-Vester \& Sander, 2016; Lörz, 2017; Nairz-Wirth et al., 2017). While internationally research 
on HE teaching and its dealing with diversity has a much longer tradition (e.g., Gay, 2014), this field is increasingly researched in the German context, focusing primarily on selected socio-structural categories of difference (e.g., gender, social origin, ethnicity). Keywords then include gender- or habitus-sensitive teaching (e.g., Burger \& Glathe, 2016; Rheinländer, 2015).

This article focuses on the discursive construction of students' differences in teaching in professional and media discourses. While research on the discursive construction of students in media or policy discourses exists (Brooks, 2018, 2020), it also mainly focuses on specific categories like the construction of international students (e.g., Paltridge et al., 2014). Lainio and Brooks (2021), for example, analyze the media discourse of several European countries regarding student family relations. However, neither the role of students' characteristics and practices in teaching nor the discursive expectations towards HE teachers and organizations are explicitly carved out.

\subsection{Difference, Discourses, and Environmental Expectations in Higher Education}

Following a constructivist understanding, differences are defined as socially constructed in historically and geographically situated contexts (Hirschauer, 2014). West and Fenstermaker (1995) refer to the process of the social practice of generating difference as "doing difference." Any "doing difference" is a meaningful selection from a set of competing categorizations that only creates a difference that can then make a difference (Hirschauer, 2014 , p. 183). Constructions of difference are thus contingent and have to be seen according to Giddens' (1984) understanding of the duality of structures as a precondition and result of social practices. In the context of this article, the construction of difference can be examined concerning the observed or reported practice of "doing difference" in HEI and, at the same time, in the practice of "doing difference" of writers and speakers in print media discourses when describing students.

Discourses are to be understood as regulated practices of interpretive production and construction of reality through which social knowledge stocks emerge (Keller, 2006 , p. 125). In this respect, print media are doubly involved in discourse production, as a stage for actors and as actors themselves. According to Yildiz (2006, p. 40), media discourses are means of transport through which social interpretations are reproduced and through which social perceptions are influenced, thereby also contributing to normalizations. In other words, the print media is crucially involved in what reproduces social reality as hegemonic discourse and what other interpretations, e.g., everyday experiences, are marginalized (Yildiz, 2006). While the print media mirrors a wider societal stance on a topic, the professional discourse especially (re)produces norms and taken-for-granted interpretations of the professional world of HE teachers.
An analysis of how students are portrayed in print media and professional discourse can indicate who is seen as a legitimate student or a "normal" student. The construction of difference and its evaluation in $\mathrm{HE}$ discourse are thus linked to issues of recognition. Depending on how the students or specific subgroups are constructed, particularly in the media discourse, they are seen as more or less legitimate with possible consequences for the perception of potential students and their future educational decisions and HE teachers' teaching decisions. Hence, media discourses about students shape society's perception of this group and the group itself. The professional discourse naturally has a more significant impact on the perceptions of the members of the profession.

Moreover, media discourses are places where societal demands on organizations, such as $\mathrm{HEI}$, are primarily mediated (Donges, 2006). However, the professional discourse also (re)produces expectations and norms towards $\mathrm{HEl}$. According to assumptions of neo-institutionalist organization theory, organizations are embedded in institutional environments from which demands are made (Hasse \& Krücken, 2005; Meyer \& Rowan, 1977). According to Scott's (2008) understanding of institutions, institutionalized expectations of organizations are present in the form of laws and regulations (regulative pillar), norms and standards (normative pillar), and ideas or shared conceptions of reality (culturalcognitive pillar). Organizations need to meet these expectations to be recognized as legitimate.

In summary, through discourse analysis, the article combines perspectives based on discourse and practice theory with sociological organization theory. Discourses can serve as a mirror of societal environmental expectations towards $\mathrm{HEI}$ and, at the same time, as a place where social reality is constructed through discursive practices (of "doing difference") and normalizations, (de)legitimations, inclusion, and exclusion are produced.

\section{Research Design}

This article is based on qualitative content analysis (Gläser \& Laudel, 2009) of the German weekly newspaper Die ZEIT for the print media discourse and the professional journal Forschung und Lehre (F\&L) for the professional discourse. Die ZEIT was chosen because, as part of the national quality press and as a leading national medium, it focuses on educational topics, significantly on HE. F\&L is a monthly journal published by the German Association of Universities, whose members are professors and researchers/HE teachers with a PhD in all disciplines. So, it focuses precisely on the professional group that is doing a significant amount of the HE teaching in Germany.

I analyzed 434 articles in Die ZEIT published between 2010 and 2020. Over one hundred articles covered the year 2020, showing that the attention to HE teaching increased with the pandemic situation. In the $F \& L$, 
I analyzed 256 articles; here, attention did not peak in 2020 but in the previous year, the anniversary of the Bologna Declaration.

I selected the Die ZEIT articles via the lexis nexus database with the help of a broad search query including (higher education OR university AND teaching OR lecturer* OR seminar OR stud*). In the analysis, I thus refer to articles covering the whole HE system in Germany including (public and private) universities, universities of applied sciences, and dual study programs. I examined over 2000 articles to determine whether the articles characterized, typified, or described students in the context of HE teaching, including instructional planning, curricula, courses, supervision and advising, organization, and examination. The same was done for the F\&L without a database by screening all published articles for the years 2010-2020. I mainly used inductive category building to identify both the categories of difference and the practices of how to respond to diverse students. I then grouped the multitude of students' differences and HE practices into analytical categories and then into overarching categories in the next step. In a third step, the various categories were analyzed in detail by zooming in on the assigned discourse segments and analyzing the context and connections to other categories and evaluations.

\section{Reconstructing Students' Differences and HEI Practices in the German Higher Education System}

In the following, the students' differences, legitimization, and normalization tendencies are described. Finally, practices for responding to differences are presented to capture professional and societal expectations for action in HEl.

\subsection{Major Contexts of Higher Education Teaching Discourses and the Construction of Difference}

Students in HE are categorized in DIE ZEIT and F\&L with the help of a variety of attributions of difference. Over time, no solid trends or changes can be determined in terms of which differences dominate. Still, various social debates can be identified in which different categories are invoked (see Table 1).

For example, the young age of students and a possible immaturity or lack of competencies were discussed in the debate on the shortening of upper secondary schooling and the abolition of compulsory military service, especially in 2010-2012. In the context of discussions about the Bologna Process and its consequences, students are portrayed as studying strategically, stressed, and less motivated. This debate has been significant in the professional discourse. Even 20 years after the Bologna reforms were introduced, they are still often used as a reason for negative developments in $\mathrm{HE}$ and students' characteristics. A digitization debate could also be traced. Here, the main issues discussed were the presence or absence of digital competencies on the part of students, making it possible for distance and part-time students to study, and reconcile this with work, childrearing, and caregiving responsibilities.

Interestingly, these benefits are much less important in the digital semesters during the Corona crisis. Here, the practices and felt pressures and burdens of students are discussed. Comparing the media and professional discourses indicates that the focus of the professional debates is limited to what happens in $\mathrm{HE}$, and broader societal developments like academization and school and military reforms are less critical.

Table 1. Major debates with corresponding discussed students' differences.

\begin{tabular}{|c|c|c|c|}
\hline Topics of debate & Main difference categories & Die ZEIT & F\&L \\
\hline $\begin{array}{l}\text { Abolition of compulsory military service } \\
\text { and reduction of school-time }\end{array}$ & $\begin{array}{l}\text { Age (younger students), less prepared, } \\
\text { fewer skills }\end{array}$ & 2010-2012 & \\
\hline Consequences of Bologna Process & $\begin{array}{l}\text { Strategic studying, stress, opportunistic, less } \\
\text { intrinsically motivated, absenteeism }\end{array}$ & 2010-2011 & 2010-2020 \\
\hline Academization & $\begin{array}{l}\text { VET qualification, without Abitur (HE entrance } \\
\text { qualification), part-time studying }\end{array}$ & 2013-2014 & \\
\hline Refugee migration into Germany & $\begin{array}{l}\text { Refugees, traumatic experience, } \\
\text { language skills }\end{array}$ & 2015-2016 & 2016-2018 \\
\hline Digitalization in $\mathrm{HE}$ & $\begin{array}{l}\text { Digital skills, usage of digital media, } \\
\text { part-time studying, care work }\end{array}$ & 2012-2020 & $2012-2020$ \\
\hline Corona crisis in $\mathrm{HE}$ & $\begin{array}{l}\text { Digital skills and practices, felt pressures, } \\
\text { financial burdens, working alongside } \\
\text { one's studies }\end{array}$ & 2020 & 2020 \\
\hline
\end{tabular}




\subsection{Individualized Characteristics, Competencies, and Practices as Main Differences}

What is striking is that in the overall view of the analysis in both Die ZEIT and F\&L, the majority of the used differences have a strong reference to seemingly individualized characteristics, i.e., they are more strongly related to individually ascribable characteristics and practices of students in teaching and do not obviously reference social structure-relevant groups that are differentiated by, for instance, age, social origin, or gender. Even though it is known from research on habitus that it is precisely these perceived and ascribed supposedly individual competencies, characteristics, and practices that express the individuals' social origins (Bourdieu, 1979/1999) and lead to inequalities. This is not addressed or reflected in the analyzed articles. The "individualized" categories include, for example, attributed characteristics or descriptions such as different study interests, the degree of commitment to learning, enthusiasm for studying, self-confidence, determination, perseverance, political orientation, or need for support.

In addition to these characteristics, students are also differentiated in terms of their competencies and study practices. In terms of competencies, the main issues addressed are (the lack of) math and language skills, competencies in scientific work, digital competencies, and students' organizational skills. In short, the focus here is on what in the German discourse, particularly on $\mathrm{HE}$ access, is called Studierfähigkeit (study ability) (Bernhard, 2017). In terms of practices, learners are often characterized as strategic students who are less intrinsically motivated (than in the past) and who study driven by exams and ECTS. Dropping out is also an essential and common theme. Other practices include disrupting courses by being late, drinking and eating, contributing to the course, attendance, study preparation, and inappropriate communication via email. In addition, there are other "individualized" categories such as attributions of performance, students' needs and desires, their feelings and motives for studying, and their experiences. In both discourses, the three main categories (characteristics, competencies, and study practices) were the dominant differences used to describe students. In the media, the characteristics dominated; in the F\&L, the study practices were discussed the most. Here, the articles focused more on direct didactical problems than in the media.

It is remarkable that students were less differentiated via the classic socio-structural categories. In particular, students with impairments are virtually nonexistent in the media discourse. Still, references to educational biography, transnational migration history, social origin, religion, gender, age, or life circumstances (care responsibilities, part-time work) are also rarely mentioned in contrast to the individualized categories. In the professional discourse, particularly social origin, gender, life circumstances, and transnational migration history-categories that are strongly associated with social inequality in education-are even less used to describe students. However, impairments, particularly psychological illnesses, were discussed as well as educational background. Concerning the latter, it is essential whether students have the general HE entrance qualification (Abitur) or not and can thus be expected to be prepared to go to $\mathrm{HE}$.

In contrast to the media discourses, when sociostructural categories are discussed in the professional discourses, it is mostly by citing research and less based on professional experience. During the Corona crisis and only in the media discourse, the students' financial situation and social origin were discussed more often than before. In the F\&L, the main focus in the context of the Corona crisis was on students' digital practices and their felt burdens, but not on the unequal distribution of these burdens. The interpretation of the overall low thematization of socio-structural categories may be twofold: First, these categories and related stereotypes might be less likely to be reproduced by not mentioning them. Second, however, structural inequalities that help determine success and failure in HE might also be systematically ignored. This is even truer if the link between "individualized" and social structural categories is not represented and reflected upon as is the case in the discourses.

\subsection{Normalization and (De)Legitimization}

Even though a certain type of heterogeneity is recognized as normal through the diverse representation of students, normalizations and (de)legitimations of certain groups and practices could be identified in the analysis. Here, the representation of students was quite similar in both discourses. By addressing specific categories of difference as deviant, not typical, or (almost) not worthy of mentioning, corresponding characteristics of "normal students" are simultaneously co-constructed.

A piece from Die ZEIT reads: "Our semester is quite heterogeneous. We also have students who graduated from a vocational-oriented secondary school and have already completed an apprenticeship. The age range is also quite wide, from 19 to 33. Some fellow students already have children" (Srikiow, 2014, p. 260, translation by the author). Thus, in this media quote from a student, specific groups are described as part of the university reality. However, by highlighting them, this quote simultaneously insinuates what is not yet typical. The normalization in the articles is done often through sociostructural categories and also through practices and characteristics. Normalized are the young full-time students without children, without vocational experience, but with a grammar school education (Gymnasium), without impairments, and from an academic parental home. Regarding practices and characteristics, students are described as both hard-working, reading, preparing, critical and not motivated, unreflective, unprepared, and 
distracted by digital devices. Hence, it is presented as usual that students are diverse in their characteristics. In the professional discourse, however, the more negative images of less motivated students prevail. The different speakers in the media and professional discourses might explain this difference in the articles. While in the media, a wide range of speakers-HE teachers, professors, students, politicians, educational scientists, journalists, parents, employers-are present; in the professional discourse, the majority are professors and $\mathrm{HE}$ teachers, researchers, and journalists. This leads to the question: Is a more negative image of students and more ignorance towards social inequality more widespread in the HE teaching profession?

In both discourses, normalization is not simultaneously accompanied by a (de)legitimization of the other groups. (De)legitimization in the sense of a positive (or negative) emphasis or devaluation takes place in the examined articles primarily with practices, characteristics, and competencies. In particular, practices of strategic studying are devalued, albeit described as normal due to the influence of the Bologna HE reforms in Germany. Legitimate are those who are "capable of studying," willing to perform, intrinsically motivated, curious, and broadly interested. Highly gifted students who still attend school but already take some courses at university are portrayed this way (Frühstudierende). Those with the opposite characteristics are portrayed as illegitimate: "Other faculty members in other programs...may moan that students are conformist, lethargic, uninspired, disinterested, ignorant, and without profile" (Schüle, 2017, p. 59, translation by the author).

An analysis of how different categories intersect shows that certain groups are constructed more ambivalently than others, i.e., with positively and negatively attributed evaluative categories. This ambivalence applies in the discourses, for example, to the group of vocationally qualified people without a HE entrance qualification or international students. The word "intersect" refers to the concept of intersectionality (Crenshaw, 1989), which emphasizes the multiple factors of advantage and disadvantage that intersect and overlap and can lead to empowerment or oppression. Thus, on the one hand, international and vocationally qualified students are presented as new target groups and HEI enrichment due to their experiences and different competencies. On the other hand, negative evaluations are primarily based on the attributed lack of study skills (in language or general knowledge). These students are represented as a risk for the quality of $\mathrm{HE}$ :

When another foreign student began his presentation in the seminar the other day, two students left the room because they knew that they were in for an incomprehensible lecture for the next half hour, which at no point would coalesce into a comprehensible argument. The obvious thought is to suggest to the international students that they give their presen- tations in English. However, many do not master this language either. (Oswalt \& Adams, 2017, p. 65, translation by the author)

An analysis of the intersection also demonstrates that rarely only individualized categories form patterns. Patterns build on a combination of socio-structural categories and individualized ones, and in this way, a discursive inclusion or exclusion of social groups occurs.

For example, people who are identified as migrants in the discourses are often described as students who often did not attend a Gymnasium, are partially vocationally qualified, come from a non-academic home, do not have an adequate level of knowledge, are insecure in their studies, do not have the habitus of German academic children, and are more prone to dropping out. Firstgeneration students are described in a very similar way:

Or also the "person in need of support." More often than average, he is a migrant or comes from a difficult family background. He himself hardly believes that he will successfully complete his studies-although he would have the will and the ability to do so. (Wiarda, 2011, p. 77, translation by the author)

Moreover, even when the study success of these groups is reported, it is often presented as something special.

The intersectional analytical perspective can demonstrate that (partly stigmatizing) stereotypes are reproduced (e.g., lack of study ability of professionally qualified persons), but also, in part, the multiple (dis)advantages of student groups are presented, whereby the focus on and discussion or reflection of (dis)advantages remains marginal.

\subsection{Expectations Towards Higher Education Institutions}

How should HEI and its teachers respond to the heterogeneity presented? Which societal expectations towards $\mathrm{HEI}$ become visible? Expectations can be generated through clearly communicated norms about practices judged as positive or negative and displayed standards. At the same time, societal expectations also arise just through reported practices. When practices are continuously represented, they seem normal and self-evident. They become representations of reality that are taken for granted. In the first step, an overview of the reported practices will be given. In a second step, it will be discussed how the practices are represented.

A variety of practices of responding to students in HE is discussed in Die ZEIT and F\&L. In general, $\mathrm{HE}$ (teaching) practices that answer to students' differences seems a relevant and already lived practice. The practices that were portrayed can be differentiated between the ones which are situated at the organizational level, like organizational support structures (counseling, information, preparatory courses, psychological aid centers) or teaching organization (e.g., part-time, 
long-distance studying, attendance requirements) and direct teachers' practices. On the one hand, these teachers' practices include rather unspecified didactic teaching practices (target group orientation, individualized, and competence-oriented teaching). However, on the other hand, more specific practices like the adaptation of the teaching language or content of the course, examination practices, specific didactical models and standards, and digitized teaching offerings are presented. In both discourses, there was hardly any discussion of compensational practices for students' disadvantages or of the training or coaching of teachers as a measure to raise awareness of differences.

By comparing the discourses, several major differences become apparent. Teachers' practices are much more important in the F\&L, whereas the media articles tend to focus more on the students and less on HE teaching. This focus on teaching practices in F\&L was particularly strong during the Corona crisis, sometimes even without reference to the actual target group of these practices, the students.

In the media discourse, there was a shift during the Corona coverage. Here, specific (digital) teaching practices became much more pertinent than in previous years. From an organizational theory point of view, it seems that in situations of uncertainty and lack of common standards, media take on the task of representing the variance of practices. In this way, universities can solve the existing new challenges through imitation (DiMaggio \& Powell, 1983). On the other hand, in the professional discourse, there has already been a strong focus on digital teaching practices before.

Besides digitized teaching, the individual didactic teaching practices are in the foreground in the professional discourse. Here, the topic is addressed, also much more precisely than in DIE ZEIT, by discussing how to react, for example, to disruptions, different motivational situations, distractions, differences in performance, but also intercultural differences. While in the media coverage, most of the practices displayed are not evaluated positively or negatively, teaching norms and standards are established in the F\&L, corresponding to the professional mandate of such a journal. With the help of checklists, for instance, clear normative recommendations for actions are given:

For this, the following checklist can be helpful: Speak slowly and well-articulated; make sure you are understood regularly; give written overviews/definitions; use visualizations. (Queis, 2010, p. 669, translation by the author)

Looking at the extent to which practices are thematized in connection with categories of difference, few recurring patterns can be identified. These connections exist primarily with socio-structural categories and less with individualized characteristics, competencies, and traits in the media discourse. In the professional discourse, the latter happens more often. For example, individual pedagogical practices such as topic selection, good presentation techniques, and innovative media use are seen as ways to motivate students to attend and participate.

While in the professional discourse, socio-structural categories are less discussed and related to practices, in the media, this is the case, particularly concerning the earlier described intersectional groups. For example, support structures are strongly thematized concerning student groups with increased dropout risk or support needs (international, "first-generation," professionally qualified students). The organization of teaching is often related to vocationally qualified students and especially students with children who need more flexibility in their studies due to their obligations. An adaptation of the teaching language is discussed as a reaction to international students and their language skills. In the media discourse, it can be seen that dealing with socio-structural-categorical differences of students, which often constitute the dimensions of social inequality-i.e., of disadvantages-is mainly outsourced to organizational offerings and is presented less as a task of individual teaching practice. Even though only a few practices were evaluated as positive, these organizational offerings have been predominantly described this way. Hence, practices that require institutionalization at the organizational level are more constructed as a norm than individual practices of HE teachers. Thus, in the media discourse, $\mathrm{HE}$ teachers are not normatively expected to be very sensitive to differences and, in particular, to inequalities. In the professional discourse, where social inequality is even less discussed, the expectations are also not articulated.

\section{Conclusion}

Against the backdrop of an increasingly diversified student body, this article has examined the print media and professional discourse on $\mathrm{HE}$ teaching to determine which categories of student difference are constructed as relevant in HE teaching, which categories of difference are normalized and (de)legitimized, and which societal expectations are placed on HEl for a differentiating approach to students.

In summary, the article was able to show that in the media and the professional discourses, a diverse student body is represented. However, the heterogeneity depicted in the discourses relates more to individualized attributions than to classical socio-structural categories. The focus is on individual study and performance. For the most part, however, this ignores the fact that many student characteristics, competencies, and practices and how teachers perceive them are mediated through categories such as social origin or gender. The reproduction of inequality and the accompanying discrimination is hardly discussed in the media discourse and even less in the professional one. Socio-cultural categories do not appear to be essential for professional teaching practices. 
In addition, the diversification taking place in the HE system is only partially reflected in the media. For example, students with impairments are virtually not represented in the media as students. This is problematic, as it can have consequences on the perception of potential students (with impairments) and their future educational decisions. It shows that it is still not common that students with impairments are being considered in HE practices. Inclusion has not yet arrived as an essential topic in the media discourse on university teaching, quite in contrast to the one about inclusion in schools.

Even though socio-structural categories were not mentioned much, normalizations often built on them. Legitimations of students, in turn, relate more strongly to individualizing categories that are more reminiscent of the Humboldtian ideal of the intrinsically motivated, broadly interested, research-affine, independent student. In the analysis of the intersectional interplay of the difference categories, it is striking that (stigmatizing) stereotypes are reproduced. For example, those of the (migrant) vocationally qualified students who lack essential skills due to the missing upper secondary general education and are at risk of dropping out. So, even when no or few socio-cultural categories are used to describe the ideal or legitimate student, it is clear that it is not, for instance, this group of the vocationally qualified or first-generation students who are more often described as having study issues.

The blindness to socio-structural categories and the strongly individualizing, e.g., competence-oriented, representation of students in both discourses is striking and can be interpreted as an indication of prevailing societal discourses in which individuals seen as human capital are made responsible for their own educational success in the sense of an entrepreneurial self (Bröckling, 2013). At the same time, also in pedagogical discourses, the individual is often in the center when looking, for example, at trends of individualizing, learner-centered approaches. Brandmayr (2018) shows that, for the concept of individualized learning, learning is seen to be strongly dependent on the individual capacities and the goal of the concept is to exploit individual performance potentials. But since the focus is on individual learning, collective learning support measures that are based on social conditions are neglected. Forgetting the socio-structural categories is thus partly inherent to individualizing pedagogical concepts. Hence, overall societal and pedagogical discourses can work in the same direction, which can be one explanation of the results in this article.

When analyzing the societal expectations of how HEl should deal with, for example, perceived at-risk students, the organizational level is usually addressed and not the individual teacher. In general, these practices, which require institutionalization at the organizational level (e.g., mentoring, preparatory courses, or advising), are the ones most likely to be thematized in the context of socio-structural-categorical differences. Dealing with these often inequality-relevant differences is thus outsourced to organizational offerings. In this way, the responsibility, power, and options for action that teachers at HEI have regarding the future opportunities of students are being underestimated or even ignored.

Following this logic, social educational mobility can therefore not only be facilitated by institutional (permeability) structures in the education system (Bernhard, 2019) but can also be influenced by the teachers' individual scope of action. Sensitizing HE teachers to these tasks and responsibilities, however, would then again have to be anchored structurally in the education system, for example through further obligatory training on diversity-sensitive teaching and discourses more sensitive to these topics.

\section{Acknowledgments}

I would like to thank the participants of the research colloquium at the Leibniz Center for Science and Society of the University of Hannover and the anonymous reviewers and academic editors for their insightful and valuable comments. I am also thankful to Maria Mewes, Nathalie Laun, and Angelina Quensel for their help in collecting and maintaining the researched empirical material.

\section{Conflict of Interests}

The author declares no conflict of interest.

\section{References}

Altbach, P. G., Reisberg, L., \& de Wit, H. (Eds.). (2017). Responding to massification: Differentiation in postsecondary education worldwide. Springer.

Bernhard, N. (2017). Durch Europäisierung zu mehr Durchlässigkeit? Veränderungsdynamiken des Verhältnisses von Berufs- und Hochschulbildung in Deutschland und Frankreich [Permeability through Europeanization? Change dynamics in the relationship between vocational and higher education in Germany and France]. Budrich University Press.

Bernhard, N. (2019). Répondre aux besoins des diplômés de l'enseignement professionnel allemand: Vers une perméabilité institutionnelle? [Supporting the needs of vocationally qualified students: Changes towards institutional permeability in Germany?]. Formation emploi, 146, 129-147.

Bourdieu, P. (1999). Die feinen Unterschiede. Kritik der gesellschaftlichen Urteilskraft [Distinction: A social critique of the judgement of taste] (11th ed.). Suhrkamp. (Original work published 1979)

Brandmayr, M. (2018). Chancengerechtigkeit und individualisiertes Lernen. Zur Verzerrung zweier Begriffe und ihrer ideologischen Funktion in Österreich [Equity of opportunities and individualized learning. On the distortion of two concepts and their ideological function in Austria]. Pädagogische Korrespondenz, 58, 53-73. 
Bröckling, U. (2013). Das unternehmerische Selbst: Soziologie einer Subjektivierungsform [The entrepreneurial self]. Fabricating a new type of subject]. Suhrkamp.

Brooks, R. (2018). The construction of higher education students in English policy documents. British Journal of Sociology of Education, 39(6), 745-761.

Brooks, R. (2020). Diversity and the European higher education student: Policy influencers' narratives of difference. Studies in Higher Education, 45(7), 1507-1518.

Burger, C., \& Glathe, A. (2016). Diversity-sensible Hochschullehre. Hintergründe und Lehrempfehlungen [Diversity-sensitive higher education teaching. Contexts and teaching recommendations]. In B. Berendt (Ed.), Neues Handbuch Hochschullehre [New handbook on higher education teaching] (pp. 25-40). DUZ Verlags- und Medienhaus.

Crenshaw, K. (1989). Demarginalizing the intersection of race and sex: A black feminist critique of antidiscrimination doctrine, feminist theory and antiracist politics. University of Chicago Legal Forum, 1989(1), 139-167.

DiMaggio, P., \& Powell, W. W. (1983). The iron cage revisited: Institutional isomorphism and collective rationality in organizational fields. American Sociological Review, 48(2), 147-160.

Donges, P. (2006). Medien als Institutionen und ihre Auswirkungen auf Organisationen. Perspektiven des soziologischen Neo-Institutionalismus für die Kommunikationswissenschaft [Media as institutions and their impact on organizations. Perspectives of sociological neo-institutionalism for the communication sciences]. Medien \& Kommunikationswissenschaft, 54(4), 563-578.

Duru-Bellat, M., Kieffer, A., \& Reimer, D. (2008). Patterns of social inequalities in access to higher education in France and Germany. International Journal of Comparative Sociology, 49(4/5), 347-368.

Gay, G. (2014). Culturally responsive teaching principles, practices, and effects. H. R. Milner \& K. Lomotey (Eds.), Handbook of urban education (pp. 353-372). Routledge.

Giddens, A. (1984). Die Konstitution der Gesellschaft. Grundzüge einer Theorie der Strukturierung [The Constitution of society. Outline of the theory of structuration]. Campus.

Gläser, J., \& Laudel, G. (2009). Experteninterviews und qualitative Inhaltsanalyse als Instrumente rekonstruierender Untersuchungen [Expert interviews and qualitative content analysis as instruments of reconstructive research] (3rd ed.). Springer.

Goastellec, G., \& Välimaa, J. (2019). Access to higher education: An instrument for fair societies? Social Inclusion, 7(1), 1-6. https://doi.org/10.17645/si.v7i1. 1841

Hasse, R., \& Krücken, G. (2005). Neo-Institutionalismus [Neo-institutionalism]. transcript.

Hirschauer, S. (2014). Un/doing Differences. Die Kontin- genz sozialer Zugehörigkeiten [Un/doing differences. The contingency of social belongings]. Zeitschrift für Soziologie, 43(3), 170-191.

Hopkins, L. (2011). The path of least resistance: A voice-relational analysis of disabled students' experiences of discrimination in English universities. International Journal of Inclusive Education, 15(7), 711-727.

Keller, R. (2006). Wissenssoziologische Diskursanalyse [The sociology of knowledge approach to discourse]. In R. Keller, A. Hirseland, W. Schneider, \& W. Viehöver (Eds.), Handbuch Sozialwissenschaftliche Diskursanalyse [Handbook of discourse analysis in social sciences] (pp. 115-146). Leske+Budrich.

Keller, R. (2011). The sociology of knowledge approach to discourse (SKAD). Human Studies, 34(1), 43-65.

Lainio, A., \& Brooks, R. (2021). Constructing students as family members: Contestations in media and policy representations across Europe. In R. Brooks \& S. $\mathrm{O}$ 'Shea (Eds.), Reimagining the higher education student (pp. 169-186). Routledge.

Lange-Vester, A., \& Sander, T. (Eds.). (2016). Soziale Ungleichheiten, Milieus und Habitus im Hochschulstudium [Social inequalities, milieus, and habitus in higher education]. Beltz Juventa.

Lee, J. J., \& Rice, C. (2007). Welcome to America? International student perceptions of discrimination. Higher Education, 53(3), 381-409.

Linde, F., \& Auferkorte-Michaelis, N. (2018). DiMStrategien, Strukturen und- Prozesse an Hochschulen [Diversity management (DiM) strategies, structures and processes at universities]. In F. Linde \& N. Auferkorte-Michaelis (Eds.), Diversität lernen und lehren-Ein Hochschulbuch [Learning and teaching diversity-A higher education manual] (pp. 209-218). Barbara Budrich.

Lörz, M. (2017). Soziale Ungleichheiten beim Übergang ins Studium und im Studienverlauf [Social inequalities in the transition to university and in the course of studies ]. In M. S. Baader \& T. Freytag (Eds.), Bildung und Ungleichheit in Deutschland [Education and inequality in Germany] (pp. 311-338). Springer.

Meyer, J. W., \& Rowan, B. (1977). Institutionalized organizations: Formal structure as myth and ceremony. The American Journal of Sociology, 83(2), 340-363.

Nairz-Wirth, E., Feldmann, K., \& Spiegl, J. (2017). Habitus conflicts and experiences of symbolic violence as obstacles for non-traditional students. European Educational Research Journal, 16(1), 12-29.

Oswalt, P., \& Adams, M. (2017, March 23). Ohne Worte \#: Universitäten wollen um jeden Preis internationaler werden. Leider sprechen die ausländischen Studenten kaum Deutsch. So geht es nicht weiter, sagen MARINA ADAMS UND PHILIPP OSWALT [Without words \#: Universities want to become more international at all costs. Unfortunately, the foreign students hardly speak any German. Things can't go on like this, say MARINA ADAMS AND PHILIPP OSWALT]. Die ZEIT, 65. 
Paltridge, T., Mayson, S., \& Schapper, J. (2014). Welcome and exclusion: An analysis of the Australian newspaper's coverage of international students. Higher Education, 68(1), 103-116.

Powell, J. J. W. (2016). Von Ableismus zur universal design Universität [From ableism to universal design university]. In C. Dannenbeck, C. Dorrance, A. Moldenhauer, A. Oehme, \& A. Platte (Eds.), Inklusionssensible Hochschule [Inclusion-sensitive university] (pp. 34-51). Klinkhardt.

Powell, J. J. W., \& Solga, H. (2011). Why are participation rates in higher education in Germany so low? Institutional barriers to higher education expansion. Journal of Education and Work, 24(1/2), 49-68.

Queis, D. V. (2010). Perspektivenwechsel [Change of perspectives]. Forschung und Lehre, 2010(9), 668-669.

Rheinländer, K. (Ed.). (2015). Ungleichheitssensible Hochschullehre. Positionen, Voraussetzungen, Perspektiven [Inequality-sensitive higher education teaching. Positions, prerequisites, perspectives]. Springer.

Schuetze, H. G., \& Slowey, M. (Eds.). (2012). Global perspectives on higher education and lifelong learning. Routledge.

Schüle, C. (2017, March 9). Sie sind großartig! Die neuen Studenten starren unentwegt aufs Smartphone und interessieren sich nur für sich selbst? Das ist Unsinn, findet der Dozent Christian Schüle [They are great! The new students stare incessantly at their smartphones and are only interested in themselves? That's nonsense, thinks lecturer Christian Schüle]. Die ZEIT, 59.

Scott, R. W. (2008). Institutions and organizations: Ideas and interests (3rd ed.). SAGE.

Smith, R. (2007). An overview of research on student support: Helping students to achieve or achieving institutional targets? Nurture or de-nature? Teaching in Higher Education, 12(5/6), 683-695.

Srikiow, L. (2014, May 6). Wirtschaft [Economy]. Die ZEIT, 260-264.

Statistisches Bundesamt. (2019). Entwicklung der Studienanfängerquote* in Deutschland von 2002 bis 2019 [Development of the number of first-year students* in Germany from 2002 to 2019]. https:// de.statista.com/statistik/daten/studie/72005/ umfrage/entwicklung-der-studienanfaengerquote

Stern, A., Lindemeyer, M., \& Tezcan-Güntekin, H. (2018). "Rassistische Witze"-Diskriminierungserfahrungen von Studierenden ["Racist jokes" - Students' experiences of discrimination]. Interculture Journal: Online Zeitschrift für interkulturelle Studien, 30, 11-27.

Streitwieser, B. (2014). Internationalisation of higher education and global mobility. Symposium Books.

Unangst, L., \& Streitwieser, B. (2018). Inclusive practices in response to the German refugee influx: Support structures and rationales described by university administrators. In A. Curaj, L. Deca, \& R. Pricopie (Eds.), European higher education area: The impact of past and future policies (pp. 277-292). Springer Nature.

West, C., \& Fenstermaker, S. (1995). Doing difference. Gender \& Society, 9(1), 8-37.

Wiarda, J.-M. (2011, September 22). Der Irrtum der Professoren. Eine Umfrage zeigt: Hochschullehrer haben falsche Vorstellungen vom typischen Studenten [The professors' misperception. A survey shows: University teachers have wrong ideas about the typical student]. Die ZEIT, 77.

Wolter, A., \& Schäfer, E. (2020). Geschichte der wissenschaftlichen Weiterbildung-Von der Universitätsausdehnung zur Offenen Hochschule [History of continuing academic education-From university expansion to open university]. In W. Jütte \& M. Rohs (Eds.), Handbuch Wissenschaftliche Weiterbildung [Handbook of continuing academic education] (pp. 13-40). Springer.

Yildiz, E. (2006). Stigmatisierende Mediendiskurse in der kosmopolitanen Einwanderungsgesellschaft [Stigmatizing media discourses in the cosmopolitan immigration society]. In C. Butterwegge \& G. Hentges (Eds.), Massenmedien, Migration und Integration: Herausforderungen für Journalismus und politische Bildung [Mass media, migration and integration: Challenges for journalism and political education] (pp. 37-53). Springer.

\section{About the Author}

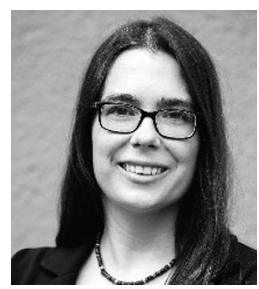

Nadine Bernhard $(\mathrm{PhD})$ is a senior researcher at the Center for Comparative and International Education at the Humboldt University Berlin. She received her PhD in sociology at FU Berlin and the Berlin Social Science Center (WZB). Her main research interests focus on comparative and international education (concentrating on vocational and higher education), institutional change, educational transfer, research on social inequality, social and institutional permeability in education systems, and diversity in education. 